Instructions for authors, subscriptions and further details:

http://brac.hipatiapress.com

\title{
Ramón Reig y Salvador Dalí: Coincidencias Biográficas y Analogías Artísticas entre Dos Pintores Coetáneos y Afines al Paisaje del Ampurdán y al "Espíritu Ampurdanés"
}

M.Nieves Sala Reig ${ }^{1}$

1) Universitat Autònoma de Barcelona (España)

Date of publication: October $3^{\text {rd }}, 2016$

Edition period: October 2016 - February 2017

To cite this article: Sala, M. (2016). Ramón Reig y Salvador Dalí: coincidencias biográficas y analogías artísticas entre dos pintores coetáneos y afines al paisaje del Ampurdán y al "espíritu ampurdanés". Barcelona, Research, Art, Creation, 4(3), 272-299. doi: 10.17583/brac.2016.2077

To link this article: http://dx.doi.org/10.17583/brac.2016.2077

\section{PLEASE SCROLL DOWN FOR ARTICLE}

The terms and conditions of use, except where otherwise noted, are related to the Open Journal System and to Creative Commons Attribution License (CC-BY). The indication must be expressly stated when necessary. 
BRAC - Barcelona Research Art Creation. Vol. 4 No. 3, October 2016, pp. 272-299

\section{Ramón Reig and Salvador Dalí: Biographical Coincidences and Artistic Analogies Between Two Contemporary Painters Attached to the Empordà Landscape and to the "Empordanese Spirit"}

M. Nieves Sala Reig

Autonomous University of Barcelona (Spain)

(Received: 5 May 2016; Accepted: 14 July 2016; Published: 3 October 2016)

Abstract

This article aims to evoke common aspects in the biography and works of two contemporary painters, Ramón Reig Corominas (Manila, 1903-Figueres, 1963) and Salvador Dalí Domènech (Figueres, 1904-1989). In the first place, il recalls the friendship and the education which both of them received from their teacher Juan Núñez, the settings which they painted together from nature and the collective exhibitions in which both artists took part. In the second place, it emphasizes the common criticisms which they aroused and the similar aspects in their painting: the verism of their technique, their attachment to the Empordà landscape and the academicism which they both cultivated. Finally, it refers to the articles written by Reig about Dalí, underlining the personality of these two artists and the esteem they manifested for each other, sharing what we might call the "Empordanese spirit".

Keywords: Dalí, landscape, Reig, Empordà, painting, verism, academicism.

2016 Hipatia Press

ISSN: 2015-8992

DOI: $10.17583 /$ brac.2016.2077

Hipatia Press

www.hipatiapress.com

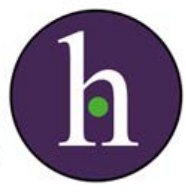


BRAC - Barcelona Research Art Creation. Vol. 4 No. 3, October 2016, pp. 272-299

\title{
Ramón Reig y Salvador Dalí: Coincidencias Biográficas y Analogías Artísticas entre Dos Pintores Coetáneos y Afines al Paisaje del Ampurdán y al "Espíritu Ampurdanés"
}

\author{
M. Nieves Sala Reig \\ Universidad Autónoma de Barcelona (España)
}

(Recibido: 5 Mayo 2016; Aceptado: 14 Julio 2016; Publicado: 3 Octubre 2016)

\section{Resumen}

El presente artículo trata aspectos comunes en la biografía y obra de los pintores coetáneos Ramón Reig Corominas (Manila, 1903 - Figueras, 1963) y Salvador Dalí Domènech (Figueras, 1904 - 1989). En primer lugar, se alude a la amistad y formación que ambos recibieron del profesor Juan Núñez, a los parajes que pintaron juntos del natural y a las exposiciones colectivas en las que coincidieron. En segunda instancia, se hace hincapié en las críticas conjuntas que recibieron y en los aspectos afines de su pintura: el verismo de su factura, el apego al paisaje del Ampurdán y el academicismo que ambos cultivaron. Finalmente se hace referencia a los artículos que Reig escribió sobre Dalí incidiendo en la personalidad de los artistas y el aprecio que se profesaron compartiendo lo que podríamos llamar el «espíritu ampurdanés».

Palabras clave: Dalí, paisaje, Reig, Empordà, pintura, verismo, academicismo.

2016 Hipatia Press

ISSN: 2015-8992

DOI: $10.17583 /$ brac.2016.2077
Hipatia Press

www.hipatiapress.com

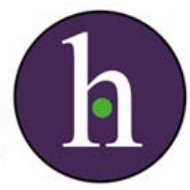




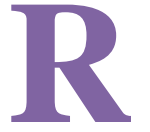

amón Reig Corominas (Manila, 1903 - Figueras, 1963) y Salvador Dalí Domènech (Figueras, 1904-1989) fueron dos pintores figuerenses, coetáneos y amigos desde la infancia, que compartieron la formación del profesor Juan Núñez, salieron a pintar juntos del natural, coincidieron en exposiciones colectivas y recibieron críticas conjuntas. A pesar de las notorias divergencias en el contenido de su pintura, existe lo que podríamos llamar un «espíritu ampurdanés»-reflejado, por ejemplo, en la complicidad entre ambos pintores o en su inclinación por plasmar el paisaje de la comarca en sus composiciones-, que los vincula en aspectos clave de su obra.

\section{Nace una Amistad. Orígenes y Etapa Formativa}

La relación entre Ramón Reig y Salvador Dalí procede de la amistad de sus respectivas familias y de la época en que se reunían, los domingos por la tarde, en la casa modernista que los Reig tenían en Vilabertrán. Los jóvenes Ramón y Salvador pintaban el paisaje de este entorno, especialmente el lago y la canonjía, y la vista panorámica que se divisaba desde la torre circular, rodeada de ventanas, de la que disponía la casa. Un auténtico mirador del Ampurdán que les permitía contemplar un horizonte único: una extensión comprendida desde el Canigó nevado hasta el golfo de Rosas. Esta perspectiva completa de la llanura altoampurdanesa influyó para siempre en la iconografía paisajística de ambos artistas.

Eran los años de la adolescencia, entre 1916 y 1920, cuando les acompañaban sus respectivas hermanas, Lolita Reig y Anna Maria Dalí, quien recordaba, en su libro Salvador Dalí visto por su hermana, aquella época: «El acuarelista Ramón Reig tenía entonces la edad aproximada de mi hermano, siendo uno de sus amigos más íntimos. Juntos contrataban modelos y pasaban largas horas pintando» (1983, p. 50). Por ejemplo, se conoce un dibujo, La Llúcia, de Reig, expuesto en 1922, así como el óleo Retrat de la Llúcia (1917), de Dalí, en los que ambos artistas retratan a Llúcia de Gispert de Moncanut, la niñera que cuidaba a Salvador y Anna Maria cuando eran niños.

Anna Maria Dalí recordaba, también, las tardes de adolescencia con su hermano Salvador y los Reig en la casa de Vilabertrán: 
Sortíem de Figueres després de dinar i tot passejant ens dirigíem a Vilabertran. Allí, la senyora Reig i la meva mare es dedicaven a visitar la finca. En Ramon i el meu germà se n'anaven a pintar, ja que, segons deien, eren pintors impressionistes. El seu lloc preferit era un llac que es trobava molt a prop de la casa; era un llac petit, abandonat. Al mig, una illeta coberta de vegetació en estat salvatge, en un dels marges, una barca varada que mai no ens vàrem atrevir a pujar-hi per lo molt desgavellada que estava. Tot l'ambient era ombrívol i els raigs de sol al filtrar-se obliquament entre l'espès fullatge, esmaltava amb claps daurats l'aigua verdosa, les falzies i la molsa. ${ }^{1}$

Vilabertrán y sus alrededores eran también el paisaje predilecto del profesor de ambos jóvenes pintores, Juan Núñez Fernández (Estepona, 1877-Barcelona, 1963), excelente dibujante, pintor y grabador, que enseñaba en el Instituto de Figueras y en la Escuela Municipal de Dibujo de la misma ciudad. Núñez solía llevar a sus alumnos a pintar del natural las inmediaciones de Vilabertrán y a interpretar los efectos de la luz según el impresionismo de aquellos tiempos. Dalí escribiría en Un Diari 1919-1920. Les meves impressions i records íntims: «Aquest vespre hem dissertat sobre l'impressionisme amb en Reig» ${ }^{2}$ (1994, p. 69). El pintor surrealista escribió en nueve ocasiones, en su diario de juventud, sobre la amistad con Reig y la complicidad que entre ambos despertaba su pasión por la pintura. Así recordaba alguna de sus salidas:

A les dues, quan el sol és més fort, emprenem amb en Reig per la carretera de Vilafant, a on cau un sol aplanador. La suor ens cau cara avall i no veiem res. Passem la tarda dibuixant sota l'ombra de les alzines, vora el cantar d'una font, vora la remor dels canyars i del riu. Les hortes són d'una promiscuïtat de llum i color i el cel és serè (...). Hi passem la tarda (1994, p. 110-111). ${ }^{3}$

Se han conservado cuadros de Reig y Dalí con la misma temática, fruto de haber pintado juntos, en más de una ocasión, los mismos parajes. Tales son El Lago de Vilabertrán (c.1916) [fig.1] y El Far d'Empordà (c.1919) [fig.2], de Reig; y El Lago de Vilabertrán (1919), El Far d'Empordà desde el Molí de la Torre (c.1919) e Iglesia y abadía de Vilabertrán (1918-1919), de Dalí, además del cuadro Dalí pintando (c.1916) [fig.3], obra de Reig, todo ello muy ilustrativo del vínculo que existía entre ambos pintores en aquellos años. Son obras de pequeño formato, pintadas sobre lienzos de trama gruesa, con un espesor considerable de pigmento y con pinceladas sueltas y vibrantes 
276 M. Nieves Sala Reig - Reig y Dalí en contraste

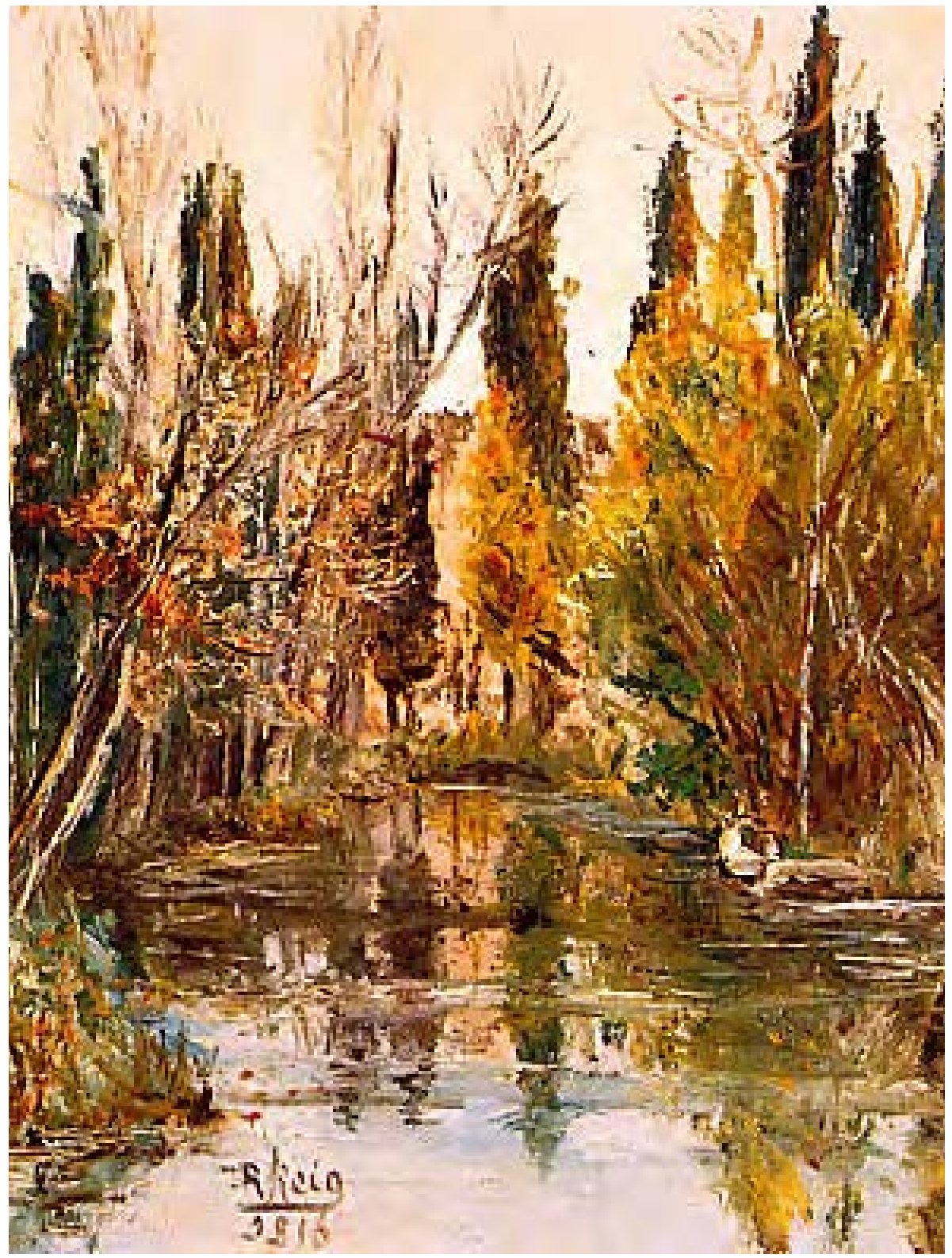

Figura 1. Ramon Reig. El Lago de Vilabertrán, (c.1916). Óleo sobre tela, 24 x 19 $\mathrm{cm}$. Colección particular. 


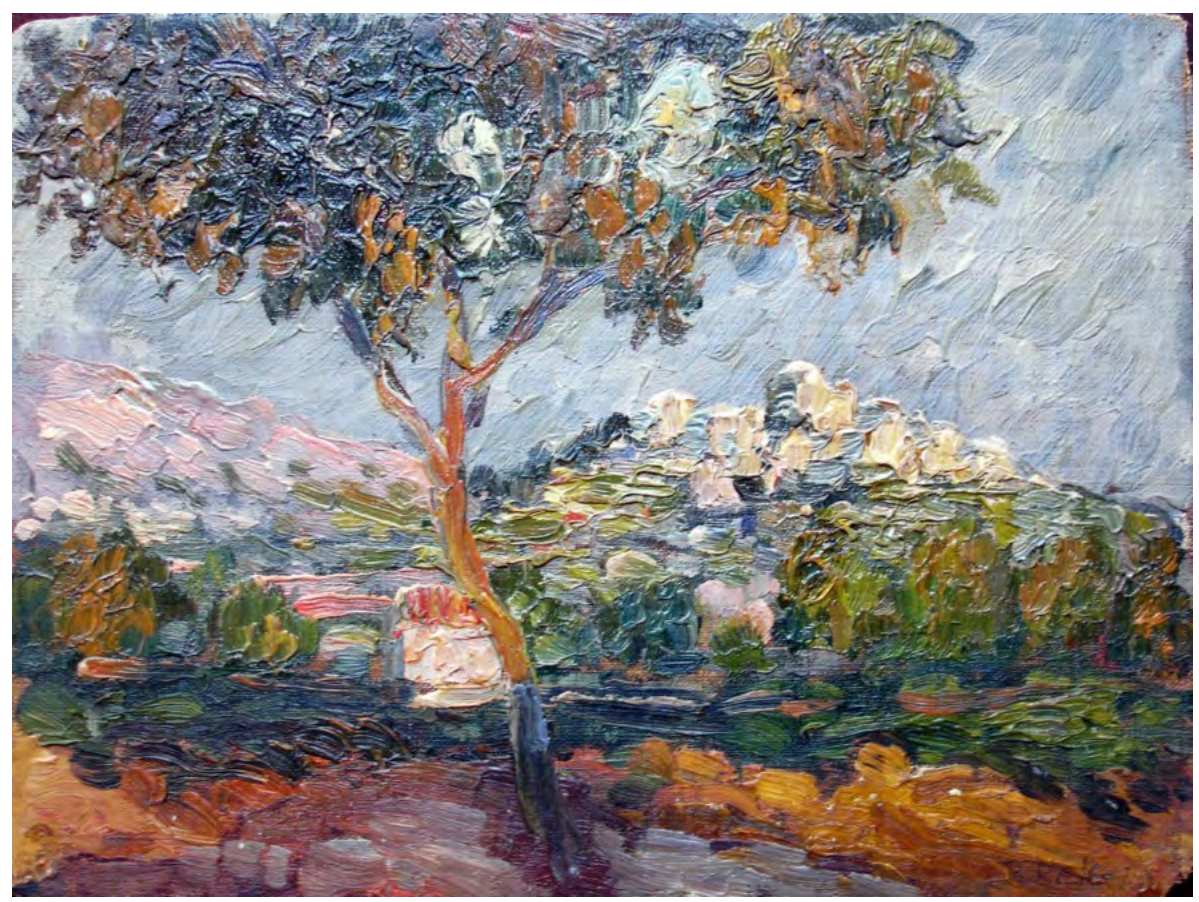

Figura 2. El Far d’Empordà (c.1919). Óleo sobre tela, 24 x 18 cm. Colección particular.

de impacto colorista y luminoso. En estas pinturas, tanto el Autorretrato de Dalí de 1920 como el Autorretrato de Reig c.1919 (véase fig. 4), revelan una estética y voluntad semejantes: exaltan la expresión del rostro sobre un fondo paisajístico lejano en el ángulo inferior del cuadro, para dejar constancia de su destino definitivo de artistas.

Reig y Dalí colaboraron también en la revista estudiantil Studium, creada en el Instituto de Figueras en 1919, junto con Joan Xirau, quien era el director, y Jaume Miravitlles y Joan Turró, quienes eran también sus redactores. Reig se dedicó a la sección literaria «Los grandes poetas ibéricos», mientras que Dalí glosó la obra de los pintores que admiraba. Es preciso señalar que ambos publicaron un texto libre inspirado respectivamente en la abadía de Santa María de Vilabertrán -como el titulado «Quadret», de Reig- y en los alrededores del pueblecito ampurdanés -leitmotiv del poema "Quan els soroll s’adormen” de Dalí, publicado en la revista ${ }^{4}$-, ambos muy significativos de cómo los dos pintores compartían las mismas vivencias y las mismas fuentes de inspiración. 
278 M. Nieves Sala Reig - Reig y Dalí en contraste

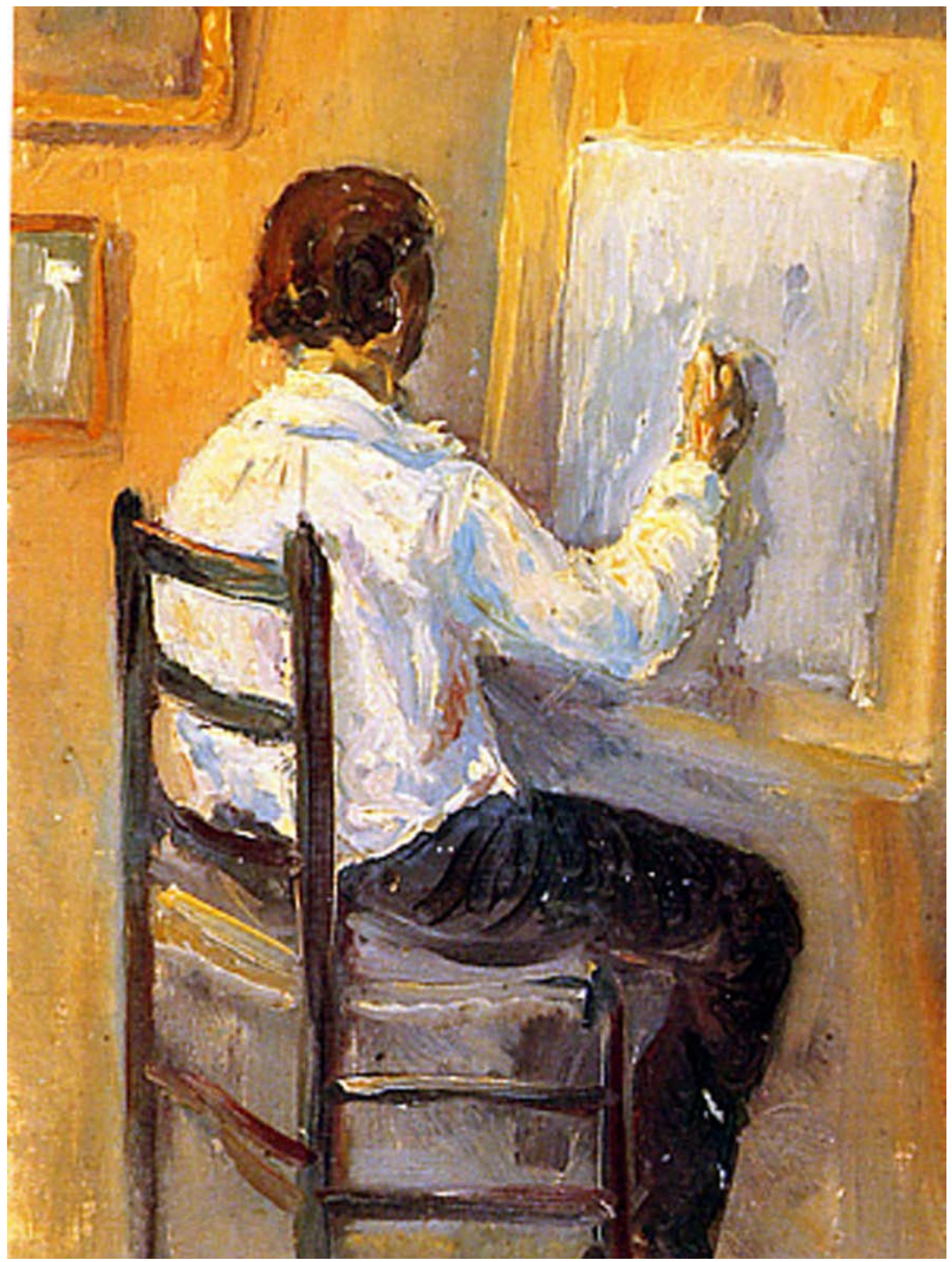

Figura 3. Dalí pintando, (c.1916). Óleo sobre tela, 35,5 x 25 cm. Colección particular. 


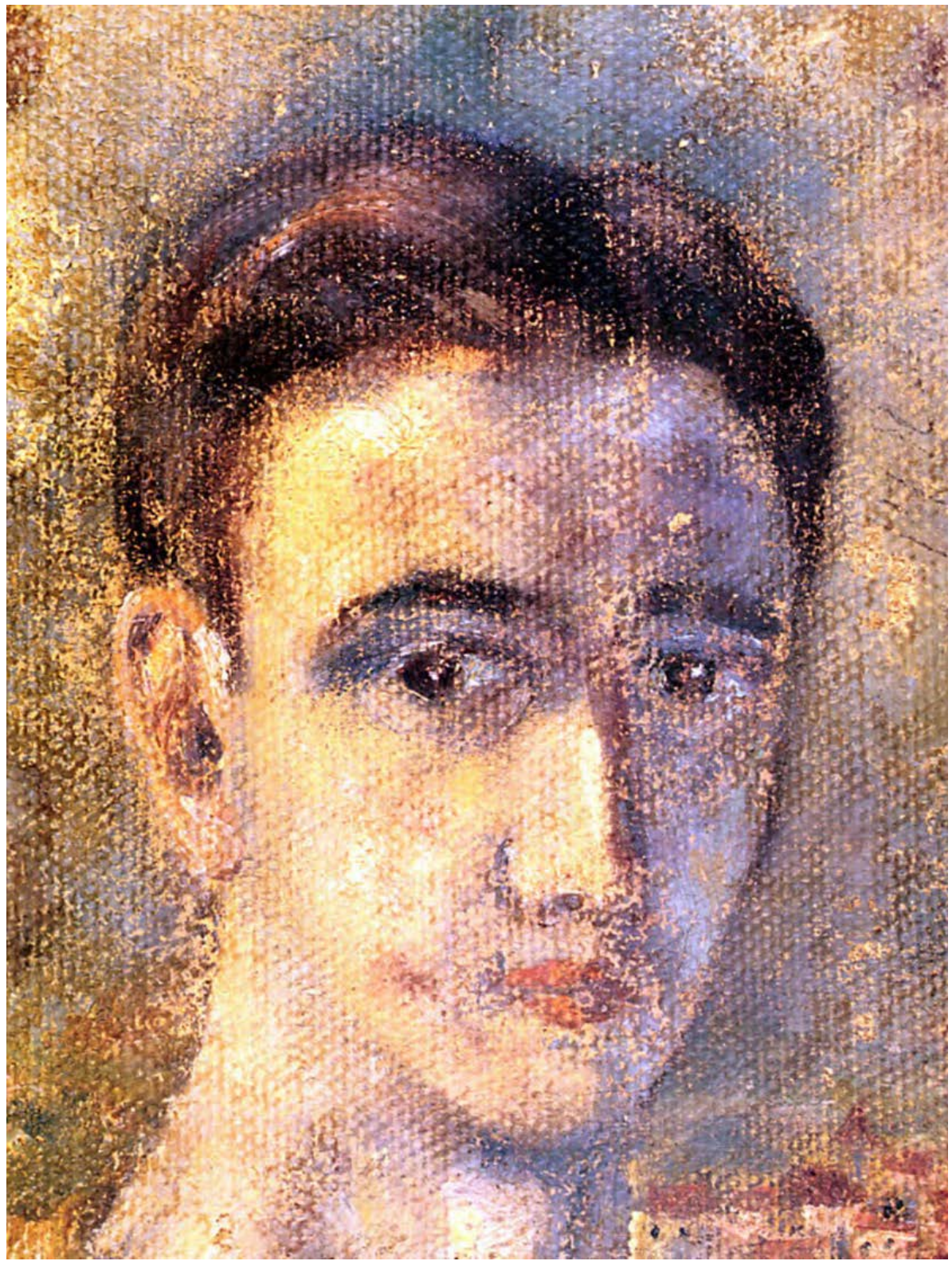

Figura 4. Autorretrato, (c.1919). Óleo sobre tela, 25 x 20 cm. Colección particular. 
Tanto Reig como Dalí empezaron a exponer en Figueras sus primeras obras de adolescente, cuyo éxito de crítica y de público no se hizo esperar. Con 13 años, Reig exhibió dos cuadros en los escaparates de los almacenes que el crítico Josep Puig Pujades tenía en Figueras, y con tan sólo 15 participó en la Exposició d'Artistes Empordanesos, celebrada en la Societat de Concerts de Figueras, junto con pintores de renombre de la comarca. Por su parte, Dalí expuso con 14 años junto a los consagrados ampurdaneses Josep Bonaterra y Josep Monturiol, también en la Societat de Concerts de Figueras, en 1919. La crítica coincidió en augurarles a ambos un prometedor futuro de artistas. El crítico y arquitecto Giralt Casadesús elogió la obra de Reig desde la Fulla Artística d'Alt Empordà: «que està molt per damunt d'altres expositors (...); té una concepció clara del color i pinta sobretot el que sent» ${ }^{5}(1918$, p. 5). Por su parte, la pintura de Dalí mereció el comentario de Puvis, pseudónimo del crítico Josep Puig Pujades, quien, en la revista Empordà Federal, calificó al pintor como «l'home que sent la llum» ${ }^{6}$ (1919, p. 3).

En el curso de los años veinte, cuando ambos artistas ya habían emprendido sus respectivos estudios universitarios, Reig en Barcelona para seguir la carrera de arquitecto y Dalí en Madrid para ingresar en la Academia de San Fernando, coincidieron en diferentes exposiciones colectivas. La primera fue en el Concurs-Exposició d'obres d'art originals d'estudiants, convocado por la Associació Catalana d'Estudiants y celebrado en la Galerías Dalmau de Barcelona, en 1922. En aquella ocasión Reig ganó el premio de la Associació con el óleo El ferial de los asnos, una arboleda de carácter impresionista reproducida en la revista D’Ací i d'Allà, mientras que Dalí mereció el premio del Rector de la Universidad con la obra Mercado. La crítica comparó la pintura de ambos artista. Octavi Saltor, por ejemplo, desde las páginas de Alt Empordà, asoció la obra de Reig «al dibuix i la reflexió madura, a l'execució feta a consciència i al seny» ${ }^{7}$, y la pintura de Dalí a un arte "colorista i de tècnica invacil.lable» ${ }^{8}$, que a diferencia de la placidez anímica de Reig, se presentaba «corprès per a la sensació motiu, mostrant una obra que respira moviment i frisança, i que és propensa a la suggestió» ${ }^{9}$ (1922, p. 2). Ese contraste inicial entre las personalidades artísticas de los dos pintores iba a ser un indicio de lo que sucedería pocos años después, cuando los propósitos pictóricos de Reig i Dalí divergirían en los contenidos, a pesar de seguir compartiendo la factura cuidadosamente realista, la afinidad por el paisaje del Ampurdán y la complicidad, es decir, ese “espíritu ampurdanés” del que se habló al principio y que conectaba la obra de ambos artistas más allá 
de sus diferencias formales y temáticas. Aquel mismo año ambos pintores participaron en la Exposició d'Artistes Empordanesos, en el Casino Menestral de Figueras, en julio de 1922, junto con los pintores Marià Llavanera, Josep Bonaterra, Josep Monturiol, Joan Pagès y Joaquim Vergés. En Empordà Federal, Puvis escribió sobre Reig: «Els seus paisatges fermament construïts acusen unes aptituds gens comunes i fan entreveure la fita a què pot arribar aquest jove artista» ${ }^{10}$ (1922, p. 2), mientras que el crítico de La Veu de l'Empordà comentó de Dalí: «Té un gran poder creador, té grans condicions d'artista: dintre seu, i ho sap exterioritzar, hi bull una revolució creadora» ${ }^{11}$ (1922, p. 4).

Efectivamente, esta «revolución creadora» llegó seis años más tarde, cuando ambos artistas coincidieron de nuevo en la Exposición Provincial de Bellas Artes, que tuvo lugar en el Casino Menestral de Figueras, en mayo de 1928. Por aquel entonces Dalí acababa de publicar El Manifest Groc, junto con Sebastià Gasch y Lluis Montayà, una auténtica declaración revolucionaria sobre el arte en la misma línea que la conferencia que pronunció para aquella ocasión : «Algunes dades per a la comprensió de la pintura més recent». Reig presentó tres dibujos y tres bodegones, mientras que Dalí expuso obras como Aparato y mano (1927) y La miel es más dulce que la sangre (1927), consideradas presurrealistas y de plena vanguardia. El crítico Josep Puig Pujades comentó la exposición en La Veu de l'Empordà, presentando a Dalí como el «propulsor de les darreres estètiques, amb les seves màquines capaces de fer rodar el cap als desconeixedors de les actuals inquietuds pictòriques» ${ }^{12} \mathrm{y}$ a Ramon Reig «admirable per uns bodegons justíssims» ${ }^{13}$ (1928, p. 5).

Finalmente, Reig y Dalí participaron también en la exposición colectiva de las Galerías Dalmau de Barcelona, en $1928{ }^{14}$, y más tarde, en la Exposició de Pintura Catalana Contemporània (1933), una muestra bajo el patrocinio de la Universidad de Barcelona que llevó a Figueras la obra de treinta y tres de los artistas más relevantes del momento, entre los cuales figuraban Joaquim Mir, Feliu Elias, Rafael Llimona, Xavier Nogués, Joaquim Sunyer y Joan Miró entre otros. Reig comentó la exposición señalando la independencia de la escuela de pintura catalana, que dejaba patente su alternancia entre la tendencia clásica y tradicional y la más moderna e innovadora. 
282 M. Nieves Sala Reig - Reig y Dalí en contraste

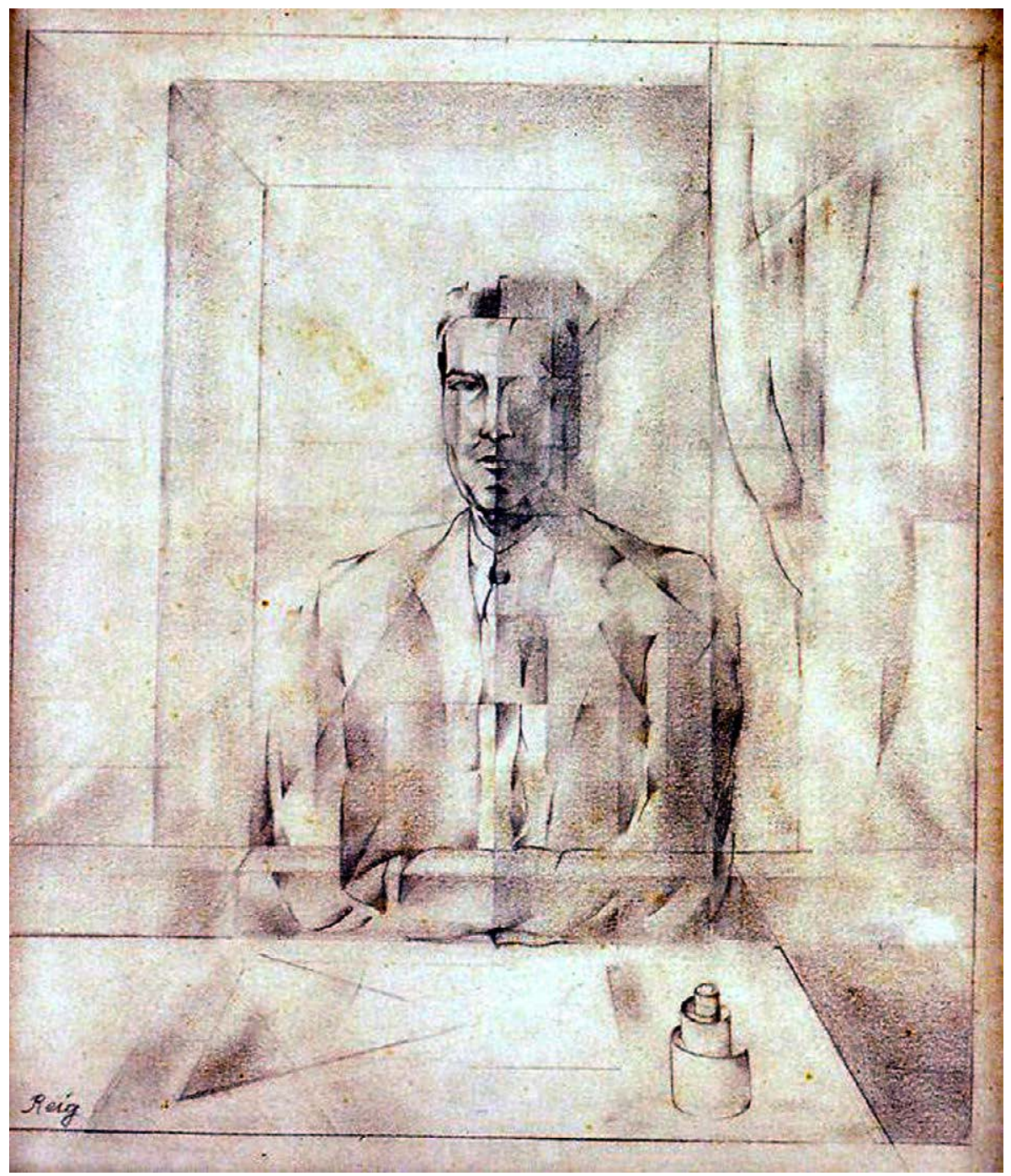

Figura 5. Figura masculina, (c.1929). Lápiz sobre papel, 28 x 25 cm. Colección particular. 

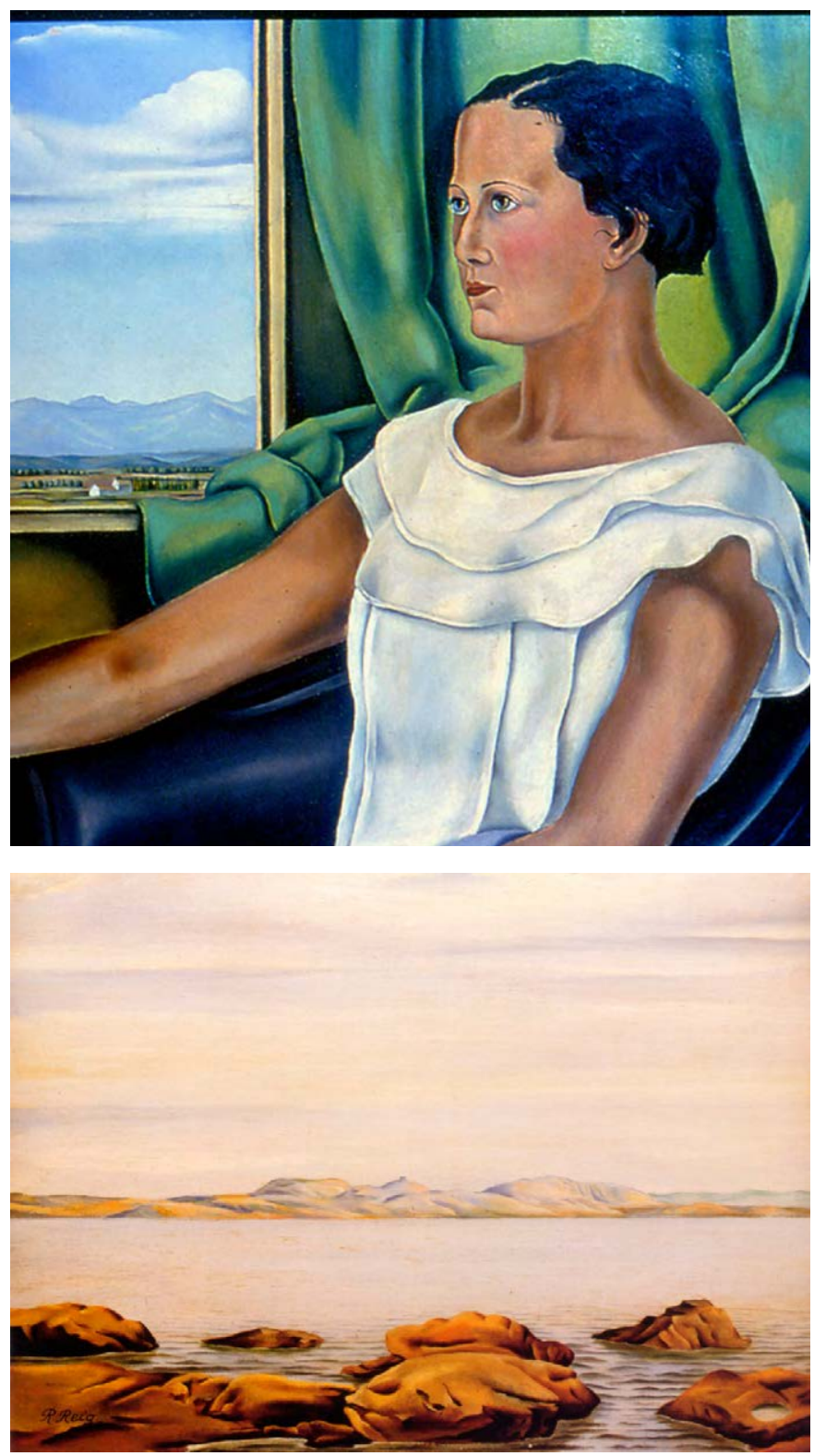

Figura 6. Figura, (1934). Óleo sobre tabla, 62 x 50 cm. Colección particular.

Figura 7. Golfo de Rosas y el Montgrí (1936), Óleo sobre tabla, 22 x $25 \mathrm{~cm}$. Colección particular. 


\section{Verismo}

A pesar de las divergencias que separan la pintura de ambos artistas desde que Dalí comenzó a experimentar con los ismos artísticos de la época ${ }^{15}$, el verismo de sus respectivas pinturas los hace afines a una obra de precisión que explora la realidad hasta el más ínfimo detalle, un verismo que es obsesivamente esmerado con la idea del oficio del pintor y que se manifiesta desde el primer momento en la obra de ambos artistas. Nos referimos a pinturas como Muchacha de espaldas (1925), que en palabras del historiador Joaquim Folch i Torres tenía el valor de "precisar l'imprecís» ${ }^{16}$ y Muchacha en la ventana (1925), de un realismo de extremada pulcritud, ambas de Dalí.

Pese a que no se han conservado óleos de Reig de aquellos años, las referencias de la prensa y los catálogos de las exposiciones con títulos como La dàlia (1927) - «una natura morta precisa, viva, apassionadament analitzada» ${ }^{17}$, según la crítica del Fulletó de la Publicitat (1927, p. 7), «un quadre d'una rara perfecció» ${ }^{18}$, y también «tela acolorida amb un carmí y un verd de Delacroix i una saviesa de dibuix, digna també de la millor tradició» 19, en palabras que el poeta Carles Fages de Climent publicó en El Dia (1927, p. 1) y La Nova Revista (1928, pp. 52-54), respectivamente-, junto con los dibujos y bodegones que Reig presentaba en las exposiciones colectivas de las innovadoras Galerías Dalmau en 1927, 1928 y 1929, corroboran este mismo verismo. Asimismo, el óleo Figura (1934) [fig.6], de Reig, con toda la precisión y limpidez de su realismo, tanto del paisaje como de la figura representados -obra que recuerda a Retrato de María Abadal (1925-1927), de Dalí-, junto con la exposición que celebró en la galerías Valenciano de Barcelona, en 1935, constituyen otra evidencia de este rasgo distintivo de su obra. Es tal la verosimilitud con la que aparecen pintadas las olas del mar en Golfo de Rosas y el Montgrí (1936) [fig.7] -verosimilitud que remite, de algún modo, a la obra de Dalí Muchacha en la ventana (1925)- que el cuadro parece traslucir el leve rumor de su cadencia. El crítico de arte Carles Capdevila hizo alusión desde La Publicitat a esa concomitancia estilística cuando se refería en los siguientes términos a las obras de Reig: «executades amb un rigor analític sorprenent. En molts moments recorda e iguala l'art miniaturístic de Dalí» ${ }^{20}$ (1935, p. 4). Se trata de una pintura analítica, clara y concisa que emprende el camino de un perfeccionamiento llevado hasta sus últimas consecuencias: la verosimilitud más extrema que constata la realidad física perceptible y revela, al mismo tiempo, su esencia invisible en términos metafísicos para retomar los propósitos surrealistas dalinianos. 
Por su parte, el crítico Alejandro Plana escribía en La Vanguardia comparando a ambos pintores:

El parentesco de estilo entre estos dos pintores no puede ser más estrecho. Y, no obstante, viene a demostrar dos cosas diametralmente opuestas. (...) Dalí se esfuerza en romper con la apariencia normal de las cosas, mediante asociaciones e interferencias de imágenes concretas, que atribuye a la fantasía en plena libertad, como la que gobierna nuestros sueños: asociaciones de panes y relojes, entre paraguas y cráneos humanos. Reig, por el contrario, no se mueve del círculo de las cosas vistas con unos ojos perfectamente despiertos. (...) A pesar de esto, hay un mismo elemento común en sus estilos, y es la concepción de la pintura, una concepción minuciosa de objetos, por un exasperado y sorprendente detallismo. En este aspecto los dos artistas rivalizan en habilidad y virtuosismo. Con esto se viene a demostrar que el sobrerrealismo, tan interesante como revolución estética en el campo de las intenciones, puede ser de un reaccionarismo extremado en la técnica. (...) El sobrerrealismo -cuanto menos en el arte de Dalíse aprovecha de los campos más trillados por el realismo que culminó en el siglo XVII. De este modo, una escuela que doctrinalmente aspira a romper las relaciones del arte con la naturaleza viene a rehacer el concepto académico, que les inspira una aversión tan profunda. Los mismos medios de expresión que le sirven a Dalí para negar la realidad son los que utiliza Ramón Reig para afirmarla. Sería difícil descubrir cuál de estos dos pintores ha influido en el otro (...), nos basta advertir su perfecto paralelismo ${ }^{21}$ (1935, p. 9).

Como puede observarse, Plana detectó y describió con absoluto acierto esa dicotomía entre el contenido opuesto y los medios de expresión análogos en la pintura de Reig y Dalí.

La representación exacta de la realidad era debida -como el mismo Reig, Dalí o el escritor Josep Pla habían comentado- a la influencia del medio físico, y, más concretamente, a la tramontana, que depura el ambiente y hace que en el Ampurdán la visión sea de una acuidad exultante. Josep Pla había escrito en la revista Destino: 
En una nota que me manda Ramón Reig sobre estos asuntos, me dice que si de alguna manera hubiera de calificarse la pintura de este grupo habría de decirse que ésta es una pintura de precisión, añadiendo que, cuando de adolescentes, Dalí y el propio Reig trataron de examinar su causa, coincidieron en que esta tendencia a la precisión era debida al hecho de vivir los artistas en un país de claridad estática, nítida, con una atmósfera perpetuamente limpiada por los golpes de tramontana, que permite distinguir los objetos más lejanos con una perfección absoluta, hasta el punto que cuando dejamos de percibirlos es porque el ojo de la vista no tiene fuerza para atraparlos. Los objetos no se pierden por interposición de brumas intermedias u obstáculos externos, sino porque la vista no da ya más de sí para captarlos (1943, p. 8).

Reig recordaba la misma conversación mantenida con Dalí en el artículo que dedicó a Juan Núñez en Ampurdán, y añadía que la enseñanza académica del profesor Núñez ponía el acento en la aplicación de una técnica rigurosa en el dibujo y la pintura que ayudara a reproducir, de la manera más fidedigna posible, la limpidez del Ampurdán:

Un algo común campea en la producción local. Ese algo común es una tendencia a la precisión y al vigor. ¿Causas? Posiblemente el país y la influencia ejercida por nuestro profesor. Recuerdo que charlando con Dalí, me decía que no se podía eludir el peso del medio en que vivimos. Un lagarto tumbado al sol en la montaña de San Pedro de Roda, de alcanzar la vista, podríamos reproducirlo con todo su detalle ya que la atmósfera no enturbiaría la visión. Y ciertamente es así. Sobre ello, el dibujo severo a que nos sometía Núñez, proporcionaba el oficio necesario para poder resolver el problema, comprometido siempre, para cuantos no fueran duchos en el menester, y todos, quién más o menos, dentro de las características de cada uno, llevamos un sello en común (1963, p. 3).

\section{Paisajismo}

El Ampurdán, origen e identidad para ambos pintores, actúa como una auténtica "musa" que motiva, nutre y lleva a la excelencia la obra de estos artistas. Fieles a la esencia del paisaje ampurdanés, Reig y Dalí plasman con la línea horizontal una tierra llana que se extiende bajo un cielo amplio, ensalzando 
una visión vasta, infinita y dada a la imaginación. Tales son los óleos Llanura del Ampurdán (c.1935) [fig.8] y Paisaje con olivo (c.1937) [fig.9], de Reig, y El farmacéutico del Ampurdán no busca absolutamente nada (1936), así como las anteriores Reminiscencia arqueológica de "El Angelus" de Millet (1933) y Vestigios atávicos después de la lluvia (1934), de Dalí, en los que el paisaje actúa como telón de fondo y refuerza al mismo tiempo el carácter enigmático de las imágenes del pintor surrealista.

Ambos artistas interpretan, no obstante, la llanura del Ampurdán de manera significativamente opuesta. Para Reig, este paisaje resulta siempre acogedor, moldeado por el hombre -con su extensión de cultivos y olivares-, al que incorpora, a partir de las acuarelas de los años cuarenta, figuras diminutas que viven y contemplan el paraje en el que se representan, en evidente contraste con la iconografía daliniana, estrechamente vinculada al Cabo de Creus, a seres espectrales y a una extensión tan inhóspita como insólita, tan onírica como misteriosa, que no dejará nunca de recrear.

Para Reig, el vínculo con el Ampurdán resulta siempre un deleite. El artista permanece conmovido por la belleza y la emoción que esta tierra le despierta, como declaró en la entrevista con Joan Teixidor, publicada en Destino:

Figueras centra no sólo mi paisaje vital sino también mi paisaje de artista (...) y mi mayor ilusión es agradecerles los excelentes ratos que me proporcionaron con una fervorosa difusión de su belleza. (...) El Ampurdán escasas veces ha sido tema de nuestros paisajistas. Para captarlo se necesita una paciente absorción en sus líneas simples, sumisas, sin aparatosidades. (...) Extensión ilimitada de cielo, llanura extensa y pródiga que dilata horizontes. Para mí contiene la mejor emoción (1940, p. 11).

La acuarela Aiguamolls (c.1960) [fig.10] sería un claro exponente de esta circunstancia.

Si el Ampurdán es la causa reiterada de la pintura de Reig, el motivo por el cual deviene pintor, y más especialmente paisajista, siendo su obra un tributo a la llanura y una de las expresiones más identificadoras de esta tierra, Dalí, que bebe y se nutre del Ampurdán, se apropia de su paisaje para no ser nunca un pintor paisajista, aunque su iconografía sea indisociable de esta misma realidad. Convencido de personificar el mismo Cabo de Creus, de encarnar la esencia de este paraje, vive la obsesión existencial de mimetizarse en él mientras explora, en palabras de Joan Gich, «les múltiples possibilitats 


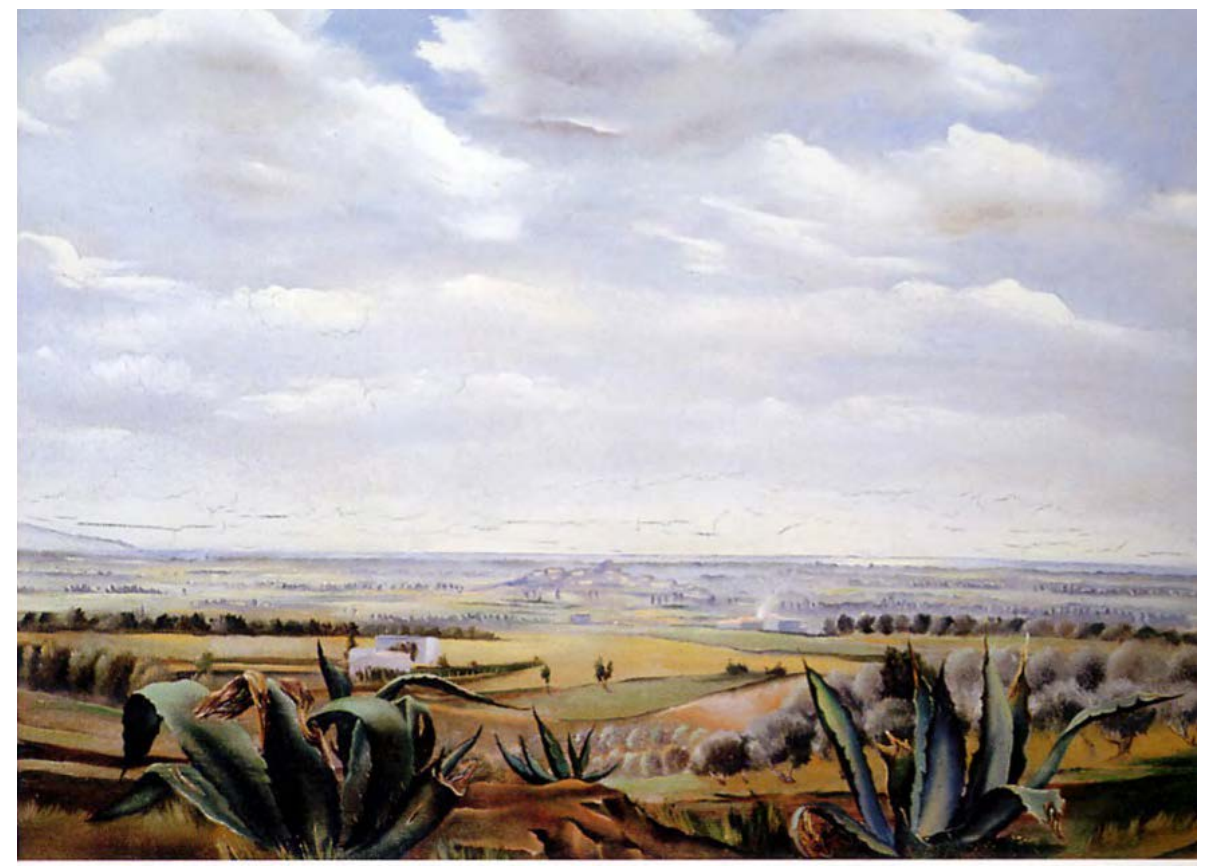

Figura 8. LLanura del Ampurdán, c.1935. Óleo sobre tabla, 26 x 38 cm. Colección particular.

estètiques, plàstiques, eròtiques, científiques de Port Lligat» ${ }^{22}$ (1971). El paisaje deviene consustancial en la pintura de Dalí, y la obra y el artista se funden y se confunden con él.

Junto a la extensión de llanura ampurdanesa, interpretada con una línea de horizonte baja, el cielo, de donde emana la luz que posibilita la percepción y vehicula la emoción, revela toda su expresividad. Para Reig, quien devendrá el pintor de los cielos ampurdaneses, la luz es también el artífice de este paisaje, transmisora de sentimientos, el elemento que propicia la calma serena del crepúsculo, la complacencia deleitante en Bahía de Rosas (c.1946) [fig.11] o el lirismo de los rayos sobre la superficie del agua en Alrededores de Figueras (c.1954) [fig.12]. En la obra de Dalí, en cambio, la luz conducirá al enigma y al misterio, a una quietud angustiante y perturbadora, acorde con su iconografía inhóspita, la de un espacio vacío interminable en obras como El sueño (1937) y La mesa solar (1936). 

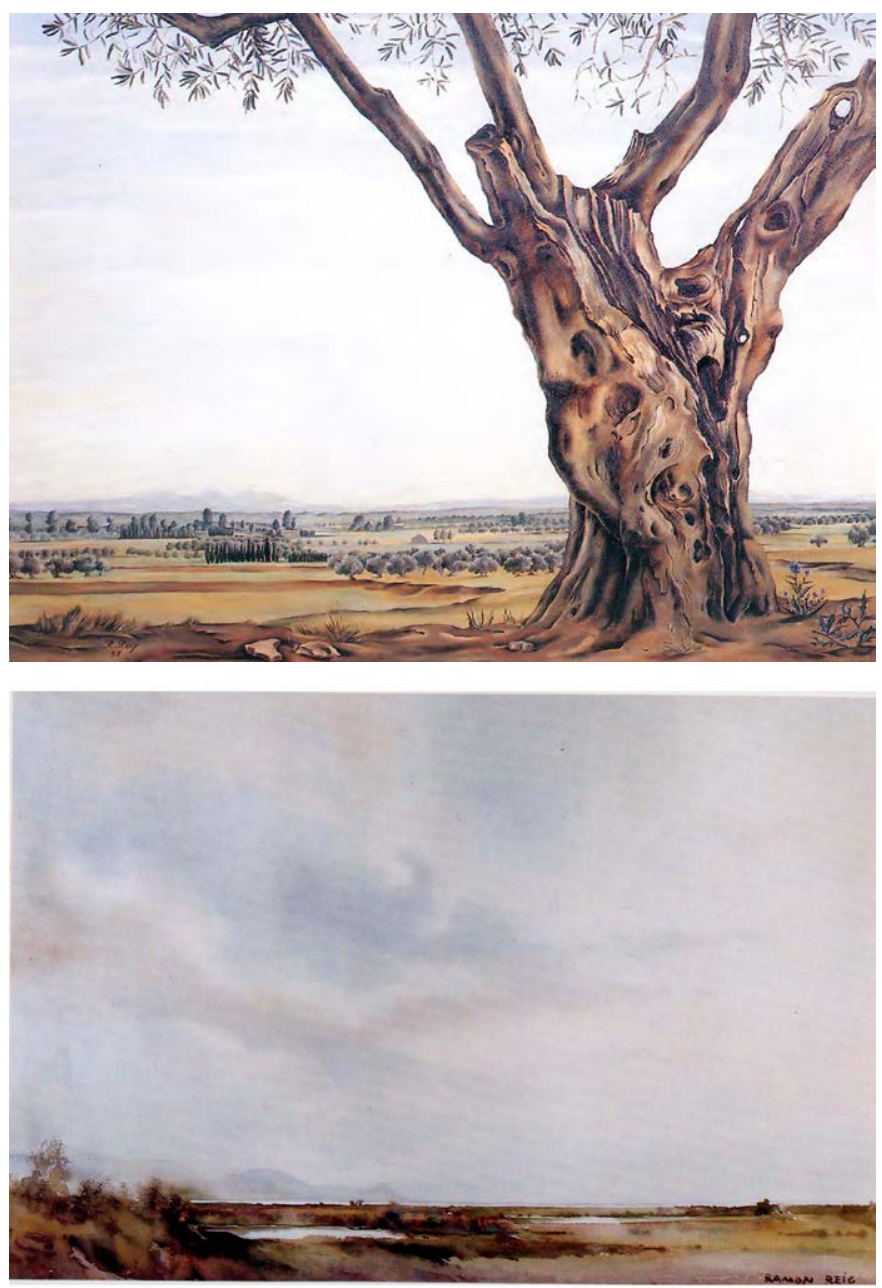

Figura 9. Paisaje con olivo, (1937). Óleo sobre tabla, 38 x 45 cm. Colección particular.

Figura 10. Aiguamolls, (c.1960). Acuarela sobre papel, 31 x $44 \mathrm{~cm}$. Colección particular. 

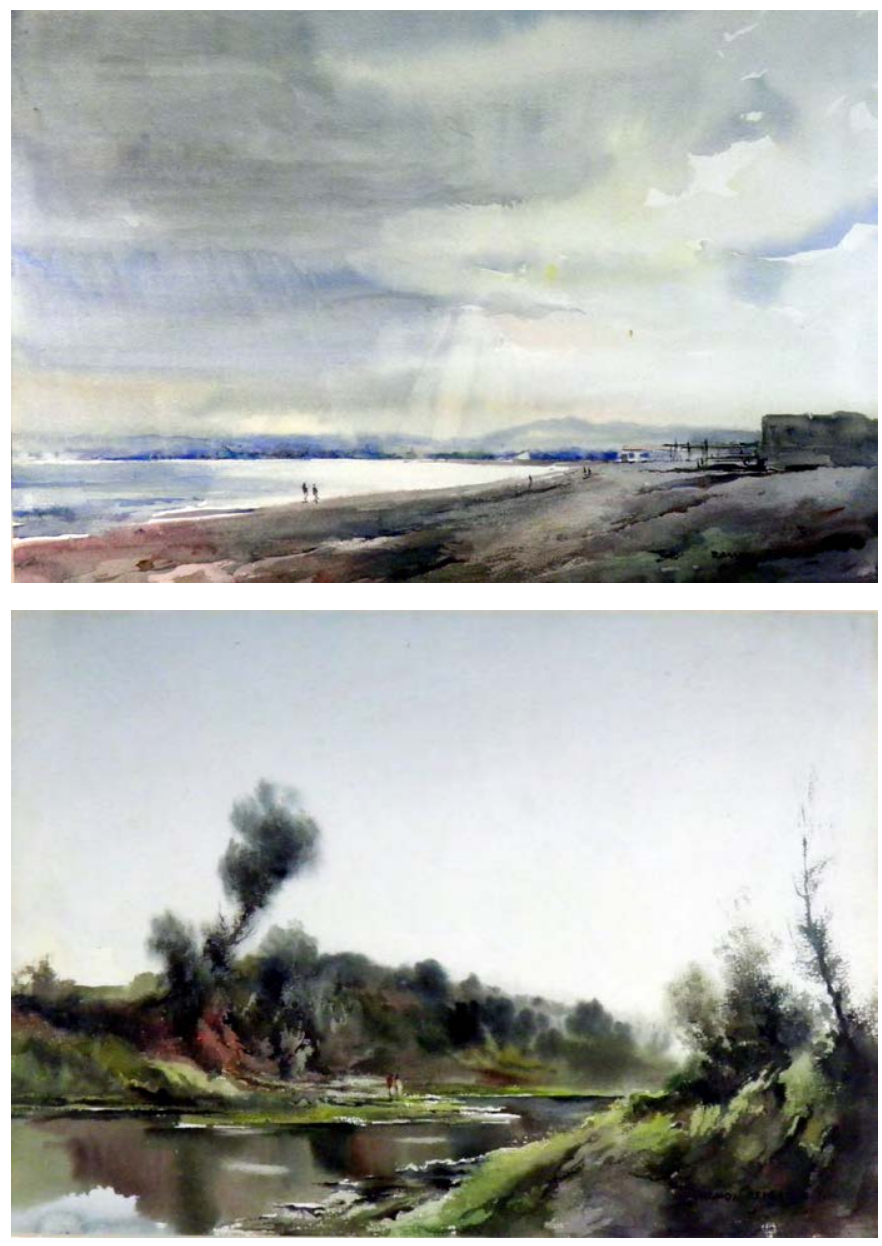

Figura 11. Bahía de Rosas, (c.1946). Acuarela sobre papel, 33 x $47 \mathrm{~cm}$. Colección particular.

Figura 12. Alrededores de Figueras, (c.1954). Acuarela sobre papel, 32 x $44 \mathrm{~cm}$. Colección particular. 


\section{Academicismo}

Es a través de la profunda admiración por el trabajo académico y el absoluto respeto por el canon y la técnica realista más cuidada que las concomitancias formales entre ambos pintores son más elocuentes. La crítica se da cuenta de ello y Miquel Utrillo comenta desde las páginas de El Día Gráfico (09.03.1935) las afinidades de Reig con la pintura de Feliu Elias -influencia que también se dejará notar en Salvador Dalí- y las relaciona con el amor al detalle y la pulcritud de la pintura de la escuela holandesa aplicada a los interiores. Tanto Reig como Dalí admiraban a Johannes Veermer -recordemos que ya de muy joven Dalí pintó Interior holandés (1916) y Reig, en su madurez, Interior con figura cosiendo (c.1935) [fig.13]- y también a Diego de Velázquez y a Ingres. En obras como Interior con desnudo (c.1942) [fig.14], de Reig, y Mi mujer desnuda, contemplando su propio cuerpo convirtiéndose en escalones, tres vértebras de una columna, cielo y arquitectura (1945), de Dalí, -como más tarde con Gala desnuda de espaldas mirando un espejo invisible (1960)-, la espalda de una figura desnuda, en la primera, y de Gala, en las dos siguientes, preside la iconografía desde el primer plano y sorprende por el academicismo y la maestría coincidentes. Además, en Interior con desnudo (1942), Reig representó su propio autorretrato en el minúsculo reflejo del botijo de vidrio a modo de homenaje a la pintura del siglo XVII.

Con el rigor académico que todo pintor debe cultivar en los diferentes géneros-figura, bodegón, paisaje y retrato-la crítica valoró muy especialmente los bodegones de Reig. Por ejemplo, desde el semanario Empordà Federal, Velívol comentaba la obra Vaso y panecillo (c.1936) [fig.15], expuesta por Reig en Figueras, en 1936:

Aquest panet ens recorda mantes produccions de Dalí del darrer temps. L'objecte arriba a assolir, per obra i gràcia del geni pictòric de l'autor, tot l'encís de les coses vives amb esperit propi; en aquest quadre Reig ha esplaiat en la puresa del vidre i en la noblesa del pa, el poder exterm del pintor, tota la bellesa que hi ha en dits objectes, encaminant en ells, el pensament d'altri per l'art guanyador del seu èmfasi suau ${ }^{23}$ (1936, p. 3). 
Por su parte, Dalí también pintó bodegones académicos como Cesta del pan, (1926) y Cesta de pan, (1945), sin contar su época mística, en la que el pintor emprendió un retorno teórico al clasicismo y al academicismo formal más elocuente.

En cualquier caso, ni Reig ni Dalí hicieron incursión alguna en el arte abstracto. Dalí sentía una profunda aversión por este tipo de arte y a Reig le procuraba una cierta desolación la polémica entre la pintura figurativa y abstracta que se produjo a finales de los años cincuenta. Es posible que lo que podríamos llamar «espíritu ampurdanés», originado por la claridad y la limpidez del ambiente de la llanura y del cielo depurado por la tramontana, hubiera modelado una estética que propugnaba la máxima acuidad perceptiva, la cual habría conducido al hiperrealismo de Dalí -o a lo que él mismo llamaba «una fotografía hecha a mano»- y a la transparencia de la acuarela hacia la que evolucionó la pintura de Reig.

\section{El Rencuentro y el «Espíritu Ampurdanés»}

En el año 1955, Reig consigue exponer una colección de pinturas procedentes del Museo del Prado en el Instituto de enseñanza Ramón Muntaner de Figueras, a la espera de poder colocarlas en un futuro museo. Dalí, que visitó la muestra, reencuentra a Reig y juntos recuerdan a su maestro Juan Núñez y aquellos primeros años de la adolescencia. Ambos artistas, separados durante décadas, se conocen a la perfección y continúan apreciándose. Es también a mediados de los años cincuenta cuando Reig veranea en Cadaqués, al lado de la casa familiar de los Dalí, donde residía Anna Maria, y visita, de vez en cuando, al pintor surrealista en Port Lligat.

Cuando en 1960, Dalí recibe la Medalla de Oro de la Diputación Provincial de Gerona, Reig escribe un artículo en el semanario Ampurdán destacando la curiosidad, el alboroto y la polémica que despertaba la pintura y el comportamiento de Dalí (1960, pp. 3-4). Para Reig es imposible separar al pintor de su obra. A su vez, comenta el discurso que el mismo Dalí pronunció en su velada homenaje. El pintor surrealista aludió a Velázquez y Reig aprovecha esta referencia para cotejar la personalidad de ambos artistas. Velázquez en un viaje a Italia, contempló la obra del pintor Rafael, conocido como «Sanzio», ante la cual pronunció un «¡No me place!», que sonaría a herejía. Con esta anécdota, Reig ilustra la manera como los artistas se oponen a la lógica y a la mentalidad generalizada del público más amplio, entroncando con la misma 
posición que Dalí mantuvo también a lo largo de su trayectoria artística.

Según sigue Reig en el citado artículo, la interpretación que suscitaba la obra de Dalí en su tierra natal no era por aquel entonces lo suficientemente comprendida,

pues no se tiene en cuenta que el artista posee el curioso don de evidenciar aquello que escapa a la percepción de los demás. Y Dalí, cuya pintura tiene mucho de mental -como dijo Leonardo- nos sirve lo que crea, percibe, piensa y forja en su fuero interno ahondando en las formas reales para mejor expresar en imágenes lo que tiene de simbolismo. Y ello no constituye una novedad; el camino que sigue tiene sus antecedentes y un gran paralelismo con el Bosco.

Y cuando el mismo Dalí aludió a Gala, con la que dijo compartir los honores de un tal homenaje, Reig asegura que Dalí era ya el Dalí de siempre cuando conoció a Gala, con toda su afirmada personalidad y agudeza. También se refiere a la falta de prestigio que el pintor surrealista tenía en Figueras en aquellos años, incidiendo en la peculiar mentalidad ampurdanesa, acaso debida a los caprichos «arrauxats» ${ }^{24}$ de la tramontana, como se había mitificado tradicionalmente. En este sentido, Reig continúa con humor:

Dalí, en una conversación de carácter particular decía que su prestigio disminuía a medida que se acercaba a su ciudad natal. (...) Lo que ocurre es lo siguiente: Los «dalís» que no pintan superabundan en Figueras. Y claro, al margen de su pintura, el hombre ni sorprende ni constituye algo fuera de serie. Es uno más entre tantos. Como ejemplar humano hallaríamos magníficos similares en Figueras y su comarca que no desdicen al lado suyo. $\mathrm{Y}$ éste es posiblemente por qué no encuentren la acogida deseada por nuestro pintor, por ser perfectamente comprendido, y lo que en otro lugar constituye una boutade, aquí tiene visos de normalidad

En cualquier caso Reig conoce y entiende la personalidad de Dalí, de quien comenta:

A Dalí no le basta el pintar; posiblemente su actitud ante la cámara fotográfica no sea la de un simple poseur y sí una extensión de su personalidad, completando lo que no cabe en la tela o escapa a la pluma. 
294 M. Nieves Sala Reig - Reig y Dalí en contraste

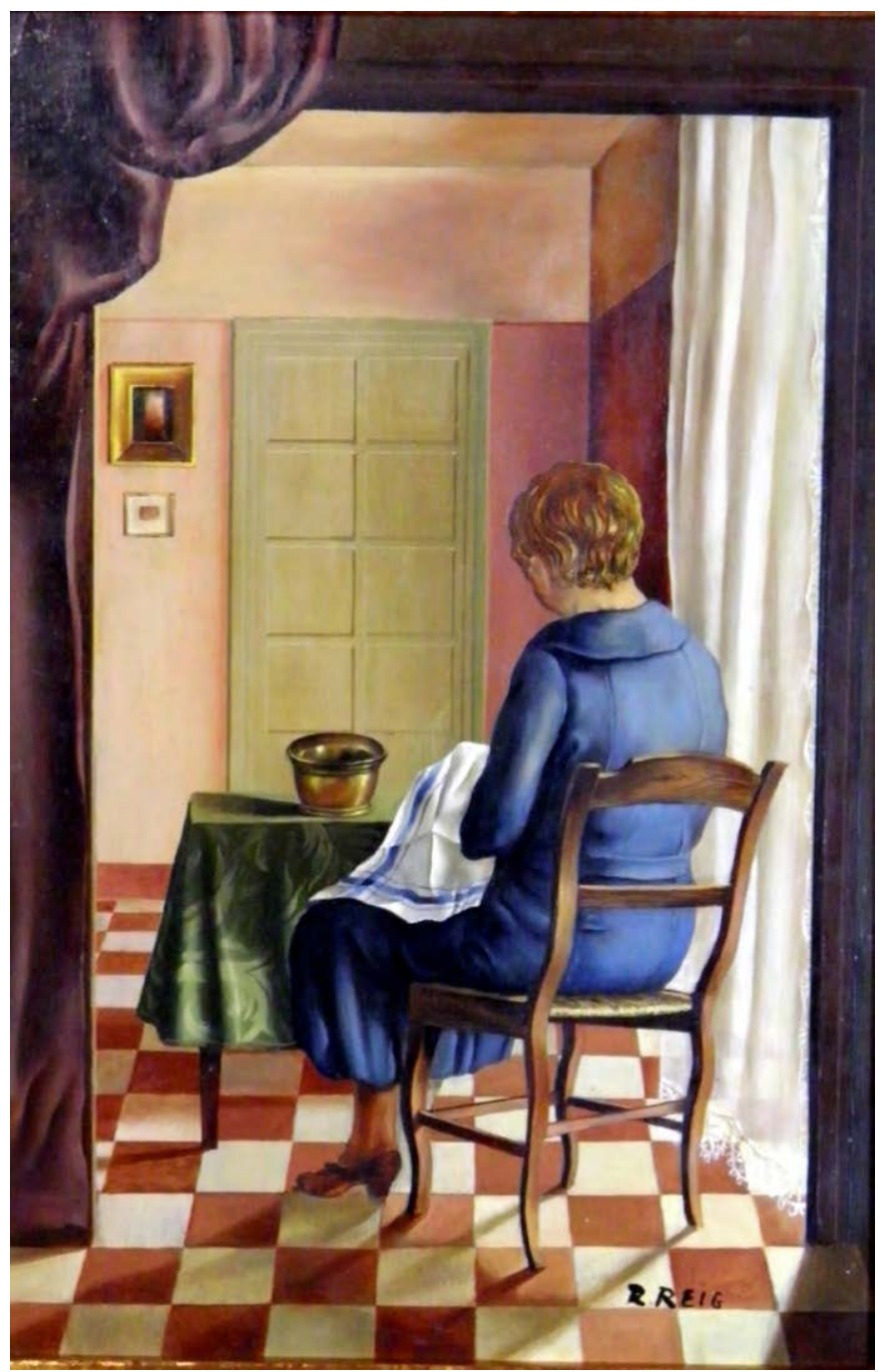

Figura 13. Interior con figura cosiendo, (c.1935). Óleo sobre tabla, 31 x $20 \mathrm{~cm}$. Colección particular. 

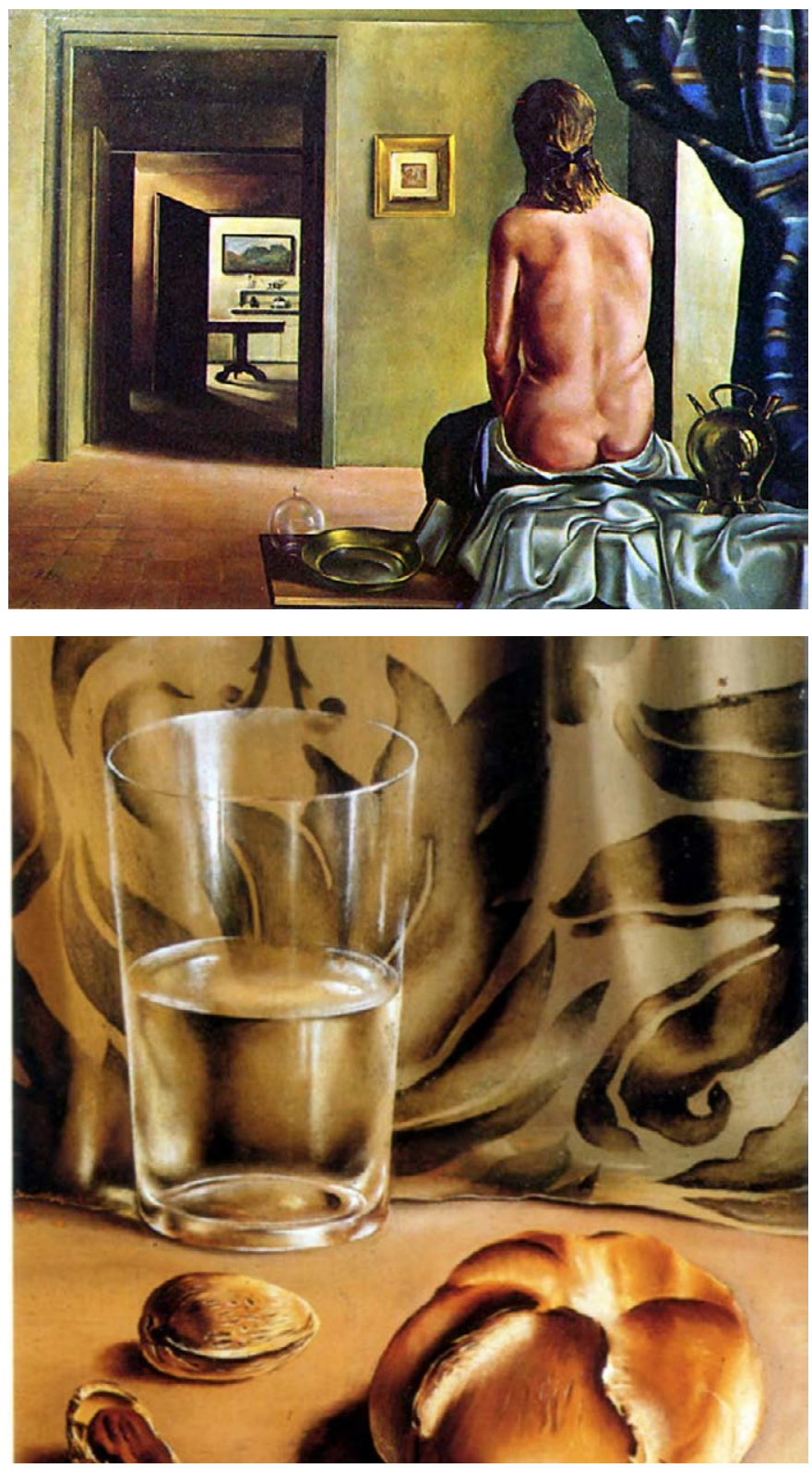

Figura 14. Interior con desnudo, (c.1942). Óleo sobre tabla, 26 x 36 cm. Colección particular.

Figura 15. Vaso y panecillo, (1936). Óleo sobre tabla, 25 x 19 $\mathrm{cm}$. Colección particular. 
En un segundo artículo publicado en el Ampurdán, Reig destacaba la merecida fama internacional de Dalí por ser un pintor infatigable entregado con auténtica vocación al arte que cultivaba. Su trabajo le merecía un profundo respeto en tanto que se había consagrado a una pintura ambiciosa nada fácil ni cómoda. También explicaba que ciertos factores extrapictóricos habían pesado negativamente en la valoración de Dalí, y concluía que permanecía todavía como un pintor «inédito» para muchos que no habían profundizado en su persona y comportamiento, lo que justificaba ciertas actitudes malinterpretadas. Finalmente, Reig defendía la creación de un museo dedicado a Dalí con el que se podría valorar, apreciar o discutir su obra,

sin que pase lo que ocurre actualmente; carente de base alguna, se le califica sin ton ni son, con fílias o fobias, pero sin ecuanimidad. Dejemos de fiscalizar a Dalí y aprendamos a juzgarle, que no es lo mismo. Así evitaremos esta crítica gratuita, nacida de la incomprensión y del desconocimiento (1961, p. 3).

La apología de Reig de la pintura y la persona de Dalí muestra la amistad y el aprecio que mantuvieron a lo largo del tiempo. A pesar de las divergencias artísticas, acaso aquello que les unió fuera su arraigo al paisaje, a su tierra, la llanura, la luz y la tramontana ampurdanesas, que con su ambiente límpido conformaría un espíritu ampurdanés, clarividente en la percepción y agudo en la comprensión de esta misma realidad. En una conversación distendida entre ambos pintores, cuando Dalí dijo que coleccionaba canteros de pan, Reig le respondió que cuando tuviera uno repetido se lo cambiaría por otro nuevo: anécdota de ese «espíritu ampurdanés» en el que vivieron y que los identificó.

\section{Notas}

${ }^{1}$ Texto mecanografiado escrito por Anna Maria Dalí. Archivo particular. «Salíamos de Figueras después de almorzar y paseando nos dirigíamos a Vilabertrán. Allí, la señora Reig y mi madre se dedicaban a visitar la finca. Ramón y mi hermano se iban a pintar ya que, según decían, eran pintores impresionistas. Su lugar preferido era un lago que se encontraba muy cerca de la casa. Era un lago pequeño, abandonado. En medio, una isleta cubierta de vegetación en estado salvaje, en uno de los márgenes, una barca varada en la que nunca nos atrevimos a subir por lo dañada que estaba. Todo 
el ambiente era sombrío y los rayos de sol al filtrarse oblicuamente entre el espeso follaje, esmaltaba de rodales dorados el agua verdosa, los helechos y el musgo» (La traducción corre a cargo de la autora. En adelante, así será en todas las citas traducidas del catalán).

${ }^{2}$ «Al atardecer, hemos disertado sobre el impresionismo con Reig».

${ }^{3}$ «A las dos de la tarde, cuando el sol es más intenso, enfilamos con Reig la carretera de Vilafant, donde cae un sol aplanador. El sudor nos cae rostro abajo y no vemos nada. Pasamos la tarde dibujando bajo la sombra de los alcornoques, cerca del cantar de una fuente, cerca del rumor de los cañizales y del río. Los huertos son de una promiscuidad de luz y color y el cielo está sereno (...). Allí pasamos la tarde».

${ }^{4}$ Los alrededores de Vilabertrán también son el escenario de su novela Tardes d'Estiu. ${ }^{5}$ «Que está muy por encima de otros expositores; (...) tiene una concepción clara del color y pinta sobre todo lo que siente».

${ }^{6} \ll$ El hombre que siente la luz».

${ }^{7}$ «Al dibujo y a la reflexión madura, a la ejecución hecha a consciencia y a la sensatez».

${ }^{8}$ «Colorista y de técnica indudable».

${ }^{9}$ «Cautivado por la sensación motivo, mostrando una obra que respira movimiento y desazón, y que es propensa a la sugestión».

${ }^{10}$ «Sus paisajes firmemente construidos acusan unas aptitudes nada comunes y hacen entrever la meta a la que puede llegar esta joven artista».

${ }^{11}$ «Tiene un gran poder creador, posee grandes condiciones de artista en su interior, y lo sabe exteriorizar, en él hierve una revolución creadora».

12 «El propulsor de las últimas tendencias estéticas, con sus máquinas capaces de marear a los desconocedores de las actuales inquietudes pictóricas».

${ }^{13}$ «Admirable por unos bodegones justísimos».

${ }^{14}$ Del 22 de octubre al 6 de noviembre.

${ }^{15}$ Dalí pasó de cultivar el puntillismo y el cubismo a nutrirse con los nuevos movimientos de carácter formal y estructurante a partir de las revistas L'Esprit Nouveau y Valori Plastici, además de recibir la influencia de pintores como Giorgio de Chirico y Carlo Carrá, proceso que culminaría con su apuesta por el surrealismo, lo cual Reig no llegaría a hacer nunca. Sólo un dibujo Figura masculina, (c.1929) [véase fig.4], está estructurado por formas geométricas de cariz cubista.

16 «Precisar lo impreciso».

${ }^{17}$ «Una naturaleza muerta precisa, viva, apasionadamente analizada».

${ }^{18}$ «Un cuadro de una rara perfección».

${ }^{19}$ «Tela coloreada con un carmín y un verde de Delacroix y una sabiduría en el dibujo digna también de la mejor tradición».

${ }^{20}$ «Ejecutadas con un rigor analítico sorprendente. En muchos momentos recuerda e iguala el arte de miniaturista de Dalí».

${ }^{21}$ Alejandro Plana cita «Rafael Dalí», creemos que por error, ya que se refería muy probablemente a Salvador Dalí. Plana acuñó el término «sobrerrealismo» para 
referirse al realismo sumamente minucioso al que se ha llamado «hiperrealismo». 22 « (...) Las múltiples posibilidades estéticas, plásticas, eróticas científicas y místicas de Port Lligat».

${ }^{23}$ «Este panecillo nos recuerda abundantes producciones de Dalí de los últimos tiempos. El objeto llega a adquirir, por obra y gracia del genio pictórico del autor, todo el encanto de las cosas vivas con espíritu propio; en este cuadro Reig ha explayado en la pureza del vidrio y en la nobleza del pan, el poder extremo del pintor, toda la belleza que hay en dichos objetos, encaminando hacia ellos, el pensamiento ajeno por el arte vencedor de su suave énfasis».

${ }^{24}$ «Alocados»

\section{Referencias}

Capdevila, C. (1935, abril 3). Galerías Valenciano. La Publicitat, p. 4.

Capdevila, C. (1927, octubre 29). L’art. Exposició inaugural de les Galeries

Dalmau. Fulletó de la Publicitat dins La Publicitat, p. 7.

Dalí Domènech, A. M. (1983). Salvador Dalí visto por su hermana.

Barcelona: Ediciones del Cotal.

Dalí Domènech, S. (1994). Diari íntim 1919-1920: Les meves impressions $i$ records íntims. Barcelona: Edicions 62.

Fages de Climent, C. (1927, Noviembre 25). Galeries Dalmau: exposició inaugural. El Dia, 2737, 1.

Fages de Climent, C. (1928, enero 13). Al marge d'unes exposicions. La Nova Revista, 13, 52-54.

Gich Bech de Careda, J. (1971). Tres visions de l'Empordà. Figueras: Museu de l'Empordà.

Giralt Casadesus, R. (1918, junio 22). L'exposició d'artistes empordanesos. Fulla Artística de l'Alt Empordà, 6, 5.

Guillamet, J.; Ferrerós, J.; Pascuet, R. (2003). Studium, La revista del jove Dalí. Figueras: Brau Edicions.

Hunding. (1922, julio 8). Exposició d'Artistes Empordanesos. La Veu de l'Empordà, 926, p. 4.

Pla, J. (1943, mayo 29). La Escuela de Figueras. Destino, 306, p. 8.

Plana, A. (1935, febrero 22). Galerías Valenciano: Ramón Reig.

La Vanguardia, p. 9.

Puig Pujades, J. (1928, junio 2). Al marge de l’Exposició provincial de Belles Arts. La Veu de l'Empordà, 1234, p. 5.

Puvis. (1919, enero 11). L'exposició de la Societat de Concerts. Empordà Federal, 415, p. 3. 
Puvis. (1922, julio 15). L'exposició d'artistes empordanesos en el Casino Menestral. Empordà Federal, 599, p. 2.

Reig Corominas, R. (1960, septiembre 14). Dalí condecorado. Ampurdán, 929, pp. 3-4.

Reig Corominas, R. (1961, agosto 9). El próximo homenaje a Dalí. Ampurdán, 974, p. 3.

Reig Corominas, R. (1963, marzo 6). Ha fallecido D. Juan Núñez. Ampurdán, 1052, p. 3.

Saltor, O. (1922, febrero 11). Pintors figuerencs. A propòsit d'una exposició escolar, organitzada per l'Associació Catalana d'Estudiants, de Barcelona. Alt Empordà, 254, p. 2.

Teixidor, J. (1940, diciembre 28). En el taller de los artistas. Con Ramón Reig. Destino, 180, p. 11.

Utrillo, M. (1935, marzo 9). Las Artes y las Letras. Ramón Reig, pinturas. El Día Gráfico, p. 17.

Velívol (1936, mayo 23). L’exposició Ramon Reig. Empordà Federal, 947, p. 3.

M. Nieves Sala Reig: Doctora en Arte por la Universitat Autonoma de Barcelona.

Contact Address: C/ Sant Pau, 37. 17600 Figueres

E-mail address: blancasala@wanadoo.fr 